\title{
Mid- to late-Holocene archaeology, environment and climate in the northeast Kurdistan region of Iraq
}

\section{Introduction}

Research carried out in Iraqi Kurdistan between 2011 and 2016 has enabled the collection of new paleoenvironmental proxy datasets. These data have the potential to reveal not only new insights on the area's climate and environmental conditions, but the coupling of these data with major archaeological finds, including excavation results, will potentially enable a better understanding of how the onset and expansion of agriculture, establishment of cities, and the creation of major empires spanning the region relate to changing regional environmental conditions. The region's long historical data, spanning from the onset of writing, long history of land use, and likely climatic change make it an ideal setting for the understanding of human-environment interactions.

This recent work in the Shahrizor valley of Iraqi Kurdistan, located in an intermontane valley between the Qaradakh range and the Zagros, has focused on the recovery of sediments, phytoliths, and archaeological data. Our intent is to use a multiproxy approach to understand environmental and climatic development, where preferably multiple points of data are used to support the position of given conclusions. Furthermore, the wider region contains abundant caves that contain speleothems (stalagmites and flowstones), enabling the obtainment of detailed climatic data on the region's ancient rainfall patterns. Only recently have speleothem data been published for this part of the Middle East (e.g., Flohr et al., 2017). Relatively limited data are also published on the regions phytoliths and sedimentary results (e.g., Marsh and Altaweel, In Press). Therefore, this work is an opportunity to obtain new paleoenvironmental and paleoclimatic data in a region were such proxies are limited.

This paper focuses on integrating archaeological, geoarchaeological, phytolith and speleothem data in order to understand the Shahrizor and northeastern Iraqi Kurdistan's paleoenvironment spanning parts of the mid- to late Holocene. Such a multiproxy approach to palaeoenvironmental and palaeoclimatic reconstructions have been long advocated because they add more robust and more highly resolved data (Rosen, 2007; O'Brien et al., 2005; Roberts et al., 2001), thus enabling researchers to better understand human-environment interactions. Data incorporated here include dated architectural finds, sediments from the Shahrizor valley, phytolith samples from archaeological and offsite trenches, and speleothem results. The objective of this paper is to, for the first time for this region, demonstrate land use and the climatic events shaping the region as agriculture began to dominate the region's economy and the rise of permanent and larger settlements commenced.

The paper will begin by providing background information on the region, including its geology and hydrology. Previous and on-going archaeological and sedimentary work is presented, where it will be utilized with the new results presented. The methods employed here, including phytolith and speleothem analyses, are then discussed. New data from 
phytoliths and speleothems are presented. A wider discussion on the broader implications of the proxies is then given, where combined results show environmental conditions for northeastern Iraq.

\section{Regional Background}

The Shahrizor and the surrounding mountains and hills (dakhs) are the result of the Arabian plate subducting under the Iranian plate: as the rock layers were folded and thrust upwards from the Tethys Sea, they formed a thrust front (the dakhs), a foreland basin (Shahrizor and related plains) and an orogenic wedge (the Zagros mountains; Karim et al., 2008). The force of this tectonic activity can be seen in the abundant folded strata found all over this area. The geology is characterized mainly by Cretaceous limestones, with some Eocene limestones in the west and Triassic limestones found in the Zagros, along with marls and sandstones (Karim et al., 2008; Ali, 2007). Because of the dominance of carbonate rocks, karstification is an important process, along with related spring formation and cave systems.

Quaternary sediments that overlie the bedrock consist mainly of colluvium at the foot of the hills and mountains and alluvial fill in the plains. There is also a contribution of aeolian material, particularly in more recent times with increasing aridity and increase of grazing and arable land (Karim et al., 2008). The Pleistocene terraces, which appear as low-lying hills in the plain are a testament of the old land surface prior to Holocene period river incision. There are few perennial rivers presently, but were likely to have been more prevalent in the past, as evidenced by the many palaeochannels in the region. Colluvium, resulting from slumps and landslides, is found along the foot of the hills and mountains, as are alluvial fans (Altaweel et al., 2012). Figure 1a provides an overview of the study region and locations of key areas discussed here. The study area lies in the southern part of Iraqi Kurdistan, close to the city of Halabja. A modern dam lake, Darband-i Khan, marks the old confluence of the Tanjero, Sirwan and Diyala rivers. The Zagros mountains lie to the east; the dakhs can be seen as linear features running on a NW to SE axis.

Figure 1 here

\section{The Shahrizor Region}

Hydrologically, the Shahrizor lies within the Shahrizor-Piramagroon basin (also known as the SE Shahrizor basin; UN-ESCWA and BRG, 2013; Al-Basrawi and Al-Jiburi 2014). Today, the climate is semi-arid Mediterranean (FAO 2008; Omer, 2011), with highly seasonal precipitation patterns: cooler, wet winters and hot, dry summers. The rainfall patterns vary across the plain, with higher precipitation in the northern part (UN-ESCWA and BGR, 2013). Mean annual precipitation in the area of the Halabja-Khurmal sub-basin is about $698 \mathrm{~mm}$ (Halabja rainfall station for the period 2002-2012), however the area experiences cycles of wet years and drought years. Maximum monthly rainfall occurs in February $(\sim 149.7 \mathrm{~mm})$ and the minimum monthly average rainfall occurs in August $(\sim 0.07 \mathrm{~mm})$. Average air temperature in the basin ranges from $3^{\circ} \mathrm{C}$ in January to $32^{\circ} \mathrm{C}$ in July; the annual average is $17-19^{\circ} \mathrm{C}$ (UN-ESCWA and BGR, 2013). 
The aquifers located in the basin consist of sedimentary rocks of marine (mainly limestone) and continental origin (sandstones and other clastic rocks; Ali, 2007). Ali (2007, p. 303) groups the formations and more recent sediments as: 1) karstic for Triassic and Jurassic rocks (TKA and JKA); 2) karstic-fissured aquifers for Cretaceous and Eocene rocks (CKFA and EKFA); 3) fissured aquifers for Cretaceous Qulqula Formation (CFA); 4) intergranular aquifers (AIA) and (EIA) for alluvium and Eocene conglomerates respectively; 5) aquitard of Tanjero rocks (TAT); and 6) complex aquifers of slide debris (SD). Well-known springs around the SE Shahrizor study area are the Sarchinar, Bestansoor, and Zalm springs.

\section{Shalaii Cave Climate and Hydrogeology}

Shalaii Cave lies due west of the SE Sharizor study area, in the hilly flanks of the Zagros $\left(35^{\circ} 08^{\prime} 42 \mathrm{~N} ; 45^{\circ} 19^{\prime} 17 \mathrm{E}\right)$ and is at 739 meters asl. The landscape surrounding the region is highly fissured and well-karstified, formed along the Ashdagh anticline composed of Oligocene rocks. The area around the cave is locally known as Garmian. The cave itself is approximately 600 meters long and is located in the Chamchamal-Sangaw basin, where the hydrogeology places it within the Chamchamal-Qadir Karam-Qara Too sub-basin (AlJiburi and Al-Basrawi, 2012). The climate in this region is semi-arid Mediterranean (AlJiburi and Al-Basrawi, 2012; Omer, 2011). The winters are cool and short; summers are typically hot; annual rainfall is about $463 \mathrm{~mm}$ (Chamchamal station measurements from 2000-2014). Maximum monthly average rainfall occurs in January (104.1 mm) and the minimum monthly average of rainfall occurs in July $(0.2 \mathrm{~mm})$, with snowfall rarely occurring in the area. The average minimum monthly temperature occurs in January (7.1 $\left.{ }^{\circ} \mathrm{C}\right)$ and the average maximum monthly temperature is in August $\left(33.2^{\circ} \mathrm{C}\right)$.

Relevant in the formation of Shalaii Cave is the Pila Spi aquifer, where infiltration capacity of the aquifer is high and rainfall is the main contributor to groundwater recharge for the aquifer. The infiltration rate is highly affected in this region by occurrences of highly fractured, cavern depressions, sinkholes, and karstified rocks that are formed; the area today is largely devoid of major vegetation. Technical hydrogeological investigations performed in Northern Iraq (Stevanovic and Markovic, 2004) have indicated recharge coefficients amount to between $30-50 \%$ of the total rainfall values for the Pila Spi aquifer. During the wet season, the reduced evaporation rate, rainfall, and even the layer slope contribute to the above-mentioned rate of the Pila Spi aquifer. Meteoric water infiltrates through the Oligocene rocks, where the water is enriched in sulphate. Surrounding springs are perennial throughout the year, depending on the runoff duration, although they vary with the daily discharge amount as described by Baba Sheikh (2000). Well-known springs around the Chamchamal-Sangaw basin are the Shalaii, Awa Spi, and Hazarkani springs.

\section{Relevant Previous and Recent Research}

Although there has been little published work in the region, archaeological activity has increased since 2011 in Iraqi Kurdistan. The data are still relatively limited, particularly in geoarchaeological and other environmental data, but new work is now enabling the 
region's environmental transformation during the Holocene to be better understood. Recent archaeological and sedimentary data are presented first, and will be combined with new phytolith and speleothem data (further below) to provide a new understanding of northeastern Iraq's environmental context.

\section{Archaeological Data}

Gurga Chiya and Tepe Marani are small, adjacent mounds in the southern part of the Shahrizor (Wengrow et al., 2016). They are situated on a Pleistocene terrace approximately $2 \mathrm{~km}$ southwest of the large Bronze-Iron Age site of Bakr Awa (Miglus et al., 2013; Figure 1b). As well as preserving the mounds for modern investigation, the mounds' raised location would have protected them from possible flooding and high rainfall discharge in much earlier periods. Excavated contexts from the two sites have produced calibrated radiocarbon dates from 7570 to $5320 \mathrm{BP}(5620-3370 \mathrm{BCE})$, suggesting intermittent occupation from Late Neolithic to Chalcolithic times. Ceramic evidence from the two sites suggests continuous occupation from the first half of the $6^{\text {th }}$ millennium BCE to the second half of the $4^{\text {th }}$ millennium BCE, although radiocarbon dates do not cover all the evident phases.

The earliest human settlement (c. 7570 - 7180 BP; 5620 - 5230 BCE) is documented at Tepe Marani, which appears to have been a small (c. 1 ha) hamlet, bounded to the west by a drainage channel. Towards the end of the site's habitation, parts of channel feature were filled with debris and paved over with carefully laid potsherds. This channel was a likely former wadi (ravine) course that silted up. This suggests the presence of flowing water directly adjacent to the main occupation area, which may have been a factor in the eventual relocation of human settlement to nearby Gurga Chiya, around the end of the sixth millennium BCE.

The earliest phases of Gurga Chiya have not yet been reached. Investigated deposits yield calibrated radiocarbon dates ranging from 6450 to $5250 \mathrm{BP}(4500-3300 \mathrm{BCE}$; Late 'Ubaid - Middle Uruk periods). Macrobotanical and faunal data attest to an arable economy based on herding cattle, sheep, and goat, with mixed farming of lentils, wheat, barley, fruit, and nuts. The west face of Gurga Chiya preserves a sequence of architectural remains dating to the Late 'Ubaid period (roughly the third quarter of the fifth millennium BCE or c. 6250-6000 BP (4300-4050 BCE)). The character of these remains suggests that drainage was an ongoing, seasonal concern for the residents. Relevant features include a substantial cobbled pathway with raised curbs, built up in a number of phases, and evidence of terracing to raise the level of adjacent buildings (Figure 2).

Figure 2 here

\section{Sedimentary Data}

Little research has been conducted on Quaternary sediments in this area, and is mainly focused on hydrogeological studies (for example, Al-Basrawi and Al-Jiburi, 2014; AlJiburi and Al-Basrawi, 2012; Karim et al., 2008; Ali, 2007) in order to investigate 
groundwater and surface water sources in the region. To fill in the gap, geoarchaeological surveys of the Shahrizor and adjacent plains were undertaken from 2011 onwards (see Altaweel et al., 2012; Marsh, 2014; Altaweel and Marsh, 2016; Marsh and Altaweel, In Press), which included analyses of satellite imagery and topographical and geological maps, as well as offsite geoarchaeological trenching and coring near Gurga Chiya and Tepe Marani (Figure 1b).

To summarize these previous geoarchaeological results: it was found that the sedimentary record was fairly similar across the Shahrizor. Most of the buried sediments were either bluish gravels or silty clays of a dark reddish brown color (5YR4/4 on the Munsell chart), indicating that a paleohydrological regime of channel cutting and siltation across the Shahrizor valley was typical. Figure 3 (Trench 1) shows a typical sedimentation sequence similar to those found in different trenches and cores (Figure 1b: C1-C7): patterns of channel cutting and deposition of sediments over time. This trench provides a useful summary for the region's sedimentation.

In Trench 1 , at about $6 \mathrm{~m}$, a gravel layer was encountered. These gravels were pinkish in color, and thus differed from the more bluish colored limestone gravels found in the upper layers, indicating that the source rock was different. There was also a sharp boundary between this gravel layer and the next silty layer above it, indicating a period of erosion (of unknown time period) between the two depositional events. It is likely that this gravel layer was deposited sometime during the Pleistocene period, with all subsequent layers above the gravel layer dating to the Holocene. That the sediments above the gravel layer represent the Holocene period is validated by pottery found at $5 \mathrm{~m}$ and $2 \mathrm{~m}$ down. Based on this archaeological evidence, the sediments between $5 \mathrm{~m}$ and $2 \mathrm{~m}$ below the surface date from about the Pottery Neolithic (earliest possible date of c. $8450 \mathrm{BP}(6500 \mathrm{BCE})$ ) to about 2450-2250 BP (500-300 BCE) or later (Altaweel et al., 2012).

Above the likely Pleistocene pinkish gravels at the bottom of the trench, there was a layer (OST1-1) of reddish brown silty clay, containing iron flecks. Within this layer was a lens (OST1-1a), which differed slightly in terms of the number of carbonate nodules present and because it contained grey mottling. OST1-1 was overlain at about $5 \mathrm{~m}$ by a slightly browner (7.5YR 4/4), siltier sediment (OST1-2); the boundary between the two was indistinct. OST1-2 contained very few calcium nodules. At about $4.5 \mathrm{~m}$, there is what appears to be a small lens of gravel, just under OST1-3. On the east section (not shown), the gravels are much more extensive, cut into OST1-2 and much more obviously form the bottom of the channel cutting of OST1-3. OST1-3 appears to have some mottling and contains some calcium nodules. It is the same color as OST1-2, and the only difference is the amount of calcium nodules encountered. OST1-2 and OST1-3 are cut into by channels (appearing to be two separate channels), which may be almost contemporaneous, which in turn are overlain by OST1-5. In the east section, there is an additional layer, a fining up sequence of gravels to sands (OST1-4) just under OST1-5. OST1-5 likely represents the final stage of the fining up sequence and consists of silty clays. OST1-4 and 5 are both reddish brown in color (5YR 4/3). OST1-5 is overlain by a soil layer. The soil layer is about 1-1.5 meters in depth, indicating a regime of environmental 'stability' in the more recent period, with less channel cutting across the plain. This suggests not only a shift in 
hydrology but also a possible reduction in precipitation and lower fluvial discharge. This phase can be roughly dated to after $2450 \mathrm{BP}(500 \mathrm{BCE})$ through the presence of Achaemenid pottery at about $2 \mathrm{~m}$ down (Altaweel et al., 2012; Marsh and Altaweel, In Press).

Figure 3 here

\section{Phytolith Research}

Vegetation communities react to changes in climate and environment driven by both natural variation and human activities. Human modification of the environment obviously has an important impact on the vegetation communities. This is not only reflected in any replacement of plants (i.e., a woodlands being cleared for cereal growing) but also will be reflected in the type of colonizing plants (such as associated agricultural weeds). Analyzing changes in plant communities, as reflected in the phytoliths assemblages, through time, gives indirect evidence of climate, environmental, economic, and land use change (Rosen, 2005).

Phytoliths ('plant rocks') are made within plants and can consist of different types of minerals including silica and calcium oxalate. Silica phytoliths, utilized in this work, are produced by plants: plants take up amorphous silica from the soil via their roots, which is then deposited and polymerized into cells and other recesses within plants (see Piperno, 2005 for more detailed discussion). When the plant decays, the hardened silica is deposited in the soil. The phytoliths can potentially preserve well and be extracted easily from the sediments. The climatic conditions in the Middle East are especially conducive for phytoliths research. A higher abundance of phytoliths is produced in high evaporative conditions, such as those found across the region. However, phytolith research is still limited in some regions, including Iraqi Kurdistan. While there has been extensive phytoliths research in the Levant (for example, Namdar et al., 2011; Ramsey et al., 2016) and Turkey (for example, Ryan, 2011; Laneri et al., 2015), there has been limited research in Iraqi Kurdistan until recently (e.g., Marsh and Altaweel, In Press).

\section{Palaeoclimate Proxies}

Precisely dated and highly resolved climate proxy records are rare in many areas of the Mediterranean. Figure 4 shows the key paleoclimate records (speleothem and lake/sea sedimentary data) in the Middle East and surrounding region, showing large spatial gaps, with most records deriving from the Levant or Turkey and Iran.

Paleoclimate records are mainly based on lake sediments from Iran (e.g., Snyder et al., 2001; van Zeist, 1966, van Zeist and Wright, 1963, Stevens et al., 2001) and Turkey (e.g., Wick et al., 2003; van Zeist and Woldring, 1978; Landmann et al., 1996; Roberts et al., 2001 Dean et al., 2015) or marine sediments from the Mediterranean and Red Seas (e.g., Rohling et al., 2015). However, many records suffer from considerable chronological uncertainties due to limitations (e.g., lack of datable material or the so-called 'hardwater effect'; Roberts et al., 2011; Stevens et al., 2001, 2006; Rohling et al., 2002 Arz et al., 
2003). Only four detailed paleoclimate series are available from Iran and Turkey, but the Lake Van, Lake Mirabad and Lake Zeribar records have a low temporal resolution (>200 years). The recently published Neor Lake multiproxy record (Sharifi et al., 2015) is a notable exception, both in terms of its dating accuracy and temporal resolution.

More precisely dated records can be obtained from speleothems (e.g., stalagmites and flowstones), which also allow an annual to monthly resolution (e.g., Bar-Matthews et al., 2003; Orland et al., 2012; Cheng et al., 2015). Oxygen $\left(\delta^{18} \mathrm{O}\right)$ and carbon $\left(\delta^{13} \mathrm{C}\right)$ isotopes are the most commonly used climate proxies in speleothems, but $\delta^{18} \mathrm{O}$ and $\delta^{13} \mathrm{C}$ calcite values can be influenced by a variety of climatic and environmental effects (e.g., air temperature, rainfall amount, seasonality, moisture source, evaporation, and cave air temperature; summarized in Lachniet, 2009). Importantly, these factors do not necessarily vary in concert and interpretation of $\delta^{18} \mathrm{O}$ calcite values often remains ambiguous. Based on published speleothem-based records from the Middle East, $\delta^{18} \mathrm{O}$ calcite values are commonly interpreted to reflect changes in the amount of rainfall and effective moisture respectively (Bar-Matthews et al., 2003; Cheng et al., 2015; Flohr et al., 2017).

Overall, the present spatial distribution of paleoclimate records from the Middle East is not sufficient to capture the complex climate dynamics in the Middle East, which are the result of major water bodies (e.g., Eastern Mediterranean and Black Sea) and complex topography (e.g., Zagros and Taurus Mountains). The addition of new paleoclimate data from Iraqi Kurdistan, in particular the speleothems from Shalaii cave, will help to fill in some of the gaps in the Near Eastern records, and will also help to increase our understanding of paleoclimate change within the Iraqi Kurdistan region.

Figure 4 here

\section{Methodology}

The archaeological and sedimentary data discussed in the previous section represent work that can be compared and utilized along with the new phytolith and speleothem results presented. We briefly discuss the methods used here (phytolith and speleothem analyses) before presenting new results.

\section{Phytolith Analysis}

Silica microfossils taken from offsite contexts provides data on vegetation change that could be the result of either or both natural climatic variation and anthropogenic modification of the environment. Phytoliths taken from onsite contexts can provide information regarding crop processing, dietary preferences, and resource use, i.e., human activities that may have had an impact on the local environment.

Seventeen samples were taken from Tepe Marani and Gurga Chiya during the 2013 season, which cover the Late Neolithic (Halaf) and Chalcolithic (Ubaid and Uruk) periods respectively (Table 1). Samples were taken from middens, surfaces, and pottery scatters. Six samples from Gurga Chiya were taken from an offsite context (Trench D). 
Additionally, 18 samples from Trench 1 that date to the Holocene are utilized along with the new results (Marsh and Altaweel, In press).

The samples were processed with the protocol developed by Rosen (2005). A subsample of $1-5 \mathrm{~g}$ of sediment (more sediment is needed for offsite samples) was sieved at $5 \mathrm{~mm}$, and then treated with a 10\% HCL (hydrochloric acid) solution to burn off the carbonates. Clays were then removed, using the settling method (based on Stokes' Law), and once dried, samples were furnaced at $500^{\circ} \mathrm{C}$ to remove any organics. Phytoliths were then separated from the sediment, using sodium polytungstate (SPT) and cleaned, dried, and mounted with Merck New Entellen.

Mounted slides were examined under an Alphashot microscope at 400x magnification. Phytoliths were identified and counted (ideally 400 for single celled examples, 100 for multicells), and recorded. After calculating numbers for total phytoliths and phytolith types per gram (Rosen, 2005), histograms (absolute counts and percentages) were created to compare different morpho- and vegetation types across chronologically sequenced samples. Water availability indices (Madella et al., 2009, using Jenkins et al.'s (2011) calculation) were also calculated for the onsite samples at Tepe Marani and Gurga Chiya and the samples from Trench 1 in order to assess the relative availability of water (i.e., soil moisture content) across a temporal scale. Generally, results over 50\% suggest relative wetness; the metric is used to compare results in this study with each other.

\section{Speleothem Analysis}

Two stalagmites (samples SHC-01 and -02; Figure 5; Table 1) were collected from Shalaii Cave (Figure 1a) in 2014. The current cave air temperature at the sampling site is $20.18 \pm 0.1{ }^{\circ} \mathrm{C}$ (measured between June 2014 and May 2015) and relative humidity is $100 \%$. Drip rates at the sampling site vary between 4408 drips and 29,199 drips per day in summer and winter respectively (Al-Hafeed, 2016) due to the strong seasonality of precipitation at the cave site where approximately $90 \%$ of total annual rainfall occurs between October and May (measured at Chamchamal station in the vicinity of Shalaii Cave, monitored between 2002 - 2014).

Stalagmite SHC-01 is approximately $33 \mathrm{~cm}$ tall and grew between 1012 (938 CE) \pm 42 and $494(1456 \mathrm{CE}) \pm 29$ years before present. Stalagmite SHC-02 is $31 \mathrm{~cm}$ long and was deposited between 8025 (6075 BCE) \pm 38 and 6977 (5027 BCE) \pm 219 yrs BP. Both stalagmites are composed of brownish calcite, whereas areas in the center of the growth axis show signs of recrystallization (Figure 5). Fine, most likely annual growth bands, consisting of couplets of brighter and darker laminae, are occasionally visible in stalagmite SHC-02. Both samples were found broken in the cave; the date ranges do not represent any meaningful break in the creation of the samples.

Uranium-series $\left({ }^{230} \mathrm{Th}\right.$ hereinafter) dates for both stalagmites were determined on a multicollector inductively coupled plasma mass spectrometer (MC-ICP-MS, Thermo-Finnigan Neptune) at the Department of Geology and Geophysics, University of Minnesota. Details of the methods, including standards used for mass fractionation and yield correction can 
be found in Cheng et al. (2013). For analysis, approximately $200 \mathrm{mg}$ of powder was drilled from the tops and bases of both stalagmites.

The thickness of annual growth bands in stalagmite SHC-02 was measured using highresolution (optical resolution of $4800 \mathrm{dpi}$ ) and the software ImageJ (2017). For stable carbon $\left(\delta^{13} \mathrm{C}\right)$ and oxygen $\left(\delta^{18} \mathrm{O}\right)$ isotope analysis, a total of 65 samples were micromilled continuously at $1 \mathrm{~cm}$ increments for both stalagmites. Powdered samples were measured using a Finnigan Delta V Advantage mass spectrometer equipped with an automated carbonate preparation system (Gas Bench II) at the Chemical Analytical Facilities (CAF) at the University of Reading, UK. Results are reported relative to the international Vienna Peedee Belemnite (VPDB) standard. Analytical errors for $\delta^{18} \mathrm{O}$ and $\delta^{13} \mathrm{C}$ are 0.07 and 0.06 $\%$ VPDB (1 $\sigma$-error), respectively (Flohr et al., 2017).

Table 1 here

Figure 5 here

\section{Results}

\section{Phytoliths from Tepe Marani and Gurga Chiya}

While the preservation of all of the samples was not sufficient to identify genera or species in many cases, as many were fractured and severely dissolved, noteworthy results were derived. Most samples, except Sample GC13E-1522, had an absolute number of phytoliths per gram below 100,000 (Figure 6a). It is likely that the preservation of the phytoliths was negatively impacted by soil chemistry and processes. The high phytolith count in GC13E-1522 may reflect a better preservation environment (in a tannur), where waste from cereal processing may have been deposited.

\section{$\underline{\text { Onsite samples }}$}

Figure $6 \mathrm{~b}$ shows the ratios of monocotyledons (generally grasses) to dicotyledons (generally trees and shrubs). Monocotyledons usually produce many more phytoliths than dicotyledons (Madella et al., 2009), so it is expected that monocotyledons will outnumber dicotyledons in samples. In some of the onsite samples, dicotyledons make up a relatively greater ratio than in other samples (i.e., TM13A-5003; TM13A-5012). This could be reflecting the use of wood on the site (as building material and well as charcoal or kindling).

Overall, the phytoliths from onsite samples reflect typical assemblages, with a mixture of cereals/grasses, wetland plants, and with some dicotyledons. Figure $6 \mathrm{c}$ depicts the relative amounts of wheat, barley, cereals (undetermined), wild grasses/weeds, and unidentified grass husks ('indet') from onsite and offsite samples. As mentioned above, many of the multicells, particularly grass husks, could not be identified further than as 'grass' (which could be wild, weed, or cereal) or as a cereal of some type (domesticated wheat and barley, but indistinguishable). No barley was identified in the phytolith samples; however 
a few examples were found in the macrobotanical samples (Wengrow et al., 2016). As such, it is possible that some of the unidentified cereal husks represent those of barley. For the onsite samples, it is most likely that the wild grasses (which include Avena and Lolium sp.) came in as weeds. Alternatively, these plants could have been used as fodder for animals.

Figure 6d (Wetland plants) compares the numbers of Phragmites australis (common reed) versus sedges. Sedges dominate the assemblages across the time periods. Reeds only make an appearance in two samples, one from Tepe Marani (TM13B-6002) and the other one from Gurga Chiya (GC13F-304). Sedge could have been preferred over reed for use in mats, baskets, and similar items (Wright, 1980). It should, however, be noted that very few Phragmite phytoliths were found in the offsite trench samples (see below).

Figure 6e compares the number of grasses (wild), cereals, wetland plants, and trees/shrubs (dicotyledons). The presence of these plants in the onsite samples reflect the use of different resources at both sites. Most of the dicotyledon phytoliths, such as polyhedrals, jigsaw shapes, and tricomes, come from leaves, with some coming from bark.

A water availability index was also calculated for the onsite samples (Table 2). The percentages were calculated by comparing the number of environmentally driven phytolith morphotypes to genetically produced morphotypes (see Madella et al., 2009; Jenkins et al., 2011). Genetically determined morphotypes, such as dumbbells/bilobes and saddles, are produced, regardless of the amount of water available; however, other types of phytoliths (such as long cells found in leaves) are sensitive to hydrological conditions and will produce more with higher levels of soil moisture (Madella et al., 2009). The percentages are consistently over $50 \%$ but with fluctuations. The fluctuations are greater in the earlier Tepe Marani site than at Gurga Chiya, which could indicate somewhat more stable climatic conditions during the earlier Chalcolithic period.

\section{Offsite Samples and Trench D from Gurga Chiya}

Samples for phytolith analysis were also taken from Trench D, next to Gurga Chiya, and compared to Trench 1 near Bakr Awa (Marsh and Altaweel, In Press; Figure 1b). These phytoliths, while not dated using absolute techniques, do provide general information on the types of vegetation in the region of Gurga Chiya/Tepe Marani throughout the Holocene.

Overall, 18 samples were analyzed from Trench 1 and range in (relative) dates from the early Holocene to the Achamaenid period (or later). The total phytoliths count was very low in most samples. Low phytoliths abundance is common in offsite samples due to biogeochemical soil processes, which can fracture and dissolve phytoliths back into soluble silica, unless there is rapid burial of the soil layer (Cabanes et al., 2011; Alexandre et al, 1997; Madella and Lancelotti, 2012). Despite these limitations, notable trends did emerge from the results overall. 
Summarizing Trench 1's results, which are used to compare to Trench D, it is evident that rondels (phytoliths coming from temperate grasses) dominate the short cell record (comparing to bilobes and saddles). This shows that a temperate climate is indicated for the whole of the Holocene. Wetland plants dominate over the grasses, indicating a much more riverine environment. The wetland plants consist of sedges, primarily, however, some reeds are present in samples P026 and 25. There is also a notable presence of jigsaw phytoliths, particularly clustering around $3 \mathrm{~m}$ to $2.5 \mathrm{~m}$ in depth (samples P026, 25, 10 and 24), which may be roughly contemporaneous with Gurga Chiya and Tepe Marani. The phytoliths, which derive from dicotyledon leaves, indicate increased water availability (Tsartsidou et al., 2007). Throughout the Holocene, it was found that there is a strong correlation between wetland plants and dicotyledons, with cereals uncorrelated, where much of the environment was riparian. Later in time, particularly after the onset of the Achaemenid period (c. 2450 BP/500 BCE), grasses became even more dominant (Marsh and Altaweel, In Press).

Figure 6a-e indicates that the overall total counts for offsite samples (Trench D) are far lower than onsite samples. Figure $6 f$ shows the comparative values of grasses, cereals, wetland plants, and trees/shrubs in the Gurga Chiya offsite context. No cereal phytoliths were found in these samples. The presence of other types of plants reflects a typical riverbank/floodplain environment, similar to the results found in Trench 1 discussed above. Pottery was found in the upper layers of the trench, which may be the result of colluvium or dumping of rubbish from the site.

Water availability indices were also calculated for Trench D and Trench 1 (Table 2). As can be seen, Trench 1 percentages for the most part consistently range from $90-100 \%$, with two exceptions, P024 and P018, where the values go down to 50\%. Trench D's results are slightly more varied. The values start at $63 \%$ and increase to $95 \%$, then suddenly drop to $54 \%$ in sample GC13D-1004.

Figure 6 here

Table 2 here

\section{Speleothem Results}

Based on linear interpolation between the Uranium-series dates, stalagmites SHC-01 and 02 grew at a fairly high growth rate of 0.637 and $0.296 \mathrm{~mm} \mathrm{yr}^{-1}$ respectively. The calculated average growth rate of stalagmite SHC-02 agrees fairly well with the average thickness of $0.416 \mathrm{~mm}$ measured on a total of 403 annual bands (Figure 7).

Oxygen isotope values of stalagmite SHC-01, deposited between 1012 (938 CE) \pm 42 and $494(1456 \mathrm{CE}) \pm 29$ years BP range from -6.34 to $-4.87 \%$ around an average of $-5.65 \%$. $\delta^{18} \mathrm{O}$ values of the older stalagmite SHC-02, deposited between 8025 (6075 BCE) \pm 38 and 6977 (5027 BCE) \pm 219 years BP, vary between -7.55 to $-5.77 \%$ around a mean of $6.54 \%$, almost $1 \%$ more negative than SHC-01 (Fig. 3). 
$\delta^{13} \mathrm{C}$ values of stalagmites SHC-01 and SHC-02 range from -11.59 to $-9.07 \%$ and -10.05 and $-7.78 \%$ respectively. Mean $\delta^{13} \mathrm{C}$ values of stalagmite SHC-01 are $-10.22 \%$ compared to $-8.94 \%$ of sample SHC-02.

Modern drip water $\delta^{18} \mathrm{O}$ values in Shalaii Cave (collected once a month between June 2014 and April 2015) average -5.61 \% (VSMOW). Using this drip water value and the modern cave air temperature of $20.18{ }^{\circ} \mathrm{C}$, the calculated (after Tremaine et al., 2011) theoretical calcite $\delta^{18} \mathrm{O}$ value of around $-6.05 \%$ is within the range of the SHC-01 $\delta^{18} \mathrm{O}$ calcite values, indicating that stalagmites in the inner part of Shalaii Cave were deposited in or very close to isotopic equilibrium due to the high relative humidity of $100 \%$ inside Shalaii Cave. The low correlation $\left(r^{2}=0.2\right.$ for SHC-01 and $\left.r^{2}=0.1\right)$ between $\delta^{18} \mathrm{O}$ and $\delta^{13} \mathrm{C}$ values (Figure 7) is further evidence that stalagmites are formed under isotopic equilibrium conditions. Thus, Shalaii Cave $\delta^{18} \mathrm{O}$ values are, therefore, primarily influenced by variations in $\delta^{18} \mathrm{O}$ of cave drip water and meteoric precipitation above the cave. Based on previously published speleothem records from the Middle East (BarMatthews et al., 2003; Göktürk et al., 2011; Cheng et al., 2015; Jex et al., 2011; Flohr et al., 2017), the amount and seasonality of precipitation and source of moisture (e.g., BarMatthews et al., 2003; Badertscher et al., 2011) appear to be the dominant controls for speleothem calcite $\delta^{18} \mathrm{O}$ values on decadal to millennial timescales, whereas fluctuations in cave air and surface air temperature have a minor or even negligible effect on stalagmite calcite values.

Figure 7 here

\section{Discussion}

\section{Sedimentary, Phytolith and Archaeological Data}

The phytolith results for Tepe Marani and Gurga Chiya are fairly typical for onsite assemblages, consisting of grasses (wild and cereal), wetland plants (mainly sedges), and dicotyledons (bushes and trees). The macrobotanical remains are also consistent with Late Neolithic to Chalcolithic assemblages, from the mid- to late Holocene, comprising of cereals, weeds, pulses (lentils, grass pea and vetches), and flax (Wengrow et al., 2016). There were no real discernable temporal or spatial trends for either the phytolith or macrobotanical assemblages, but they do indicate a continuing temperate climate throughout the period. They also indicate resource use at the sites: crop plants, wetland plants for matting, baskets and similar, and wood/branches, possibly for construction.

Additionally, the crops found in the phytoliths and macrobotanical remains indicate the two typical growing seasons in the Near East: a winter season for the cereals and a summer season for the flax and legumes. The cereals and legumes do lend support to the hypothesis of increased seasonality during this period (Late Neolithic to Chalcolithic) discussed below, with a rainy winter season (November to March) and hot, dry summers (June through September). In previous research across the Shahrizor, evidence of largescale irrigation channels in sections, cuts or satellite imagery has not been encountered. It is likely that, as now, that there was ample precipitation to support rainfed or 
floodfarming techniques in the winter. It was also noted in our survey work (see also Omer, 2011) that there is limited irrigation (using springs) in the summer, to irrigate summer crops such as vegetables, fruit trees, etc. In the Late Neolithic to early and middle Chalcolithic periods, the precipitation was high enough for rainfed or floodfarming around Gurga Chiya/Tepe Marani. Based on the macrobotanical remains, however, it also seems that the summers may have been very hot, with drought conditions at times: lentils and grass pea, for instance, are both drought tolerant. Generally, these results suggest the region was not directly affected by summer Asian monsoons in the period of the site's occupation.

The flax (Linum usitatissimum) is an interesting crop, as it grows in spring and summer and requires wettish soils and irrigation. Although this crop seems to counter the argument laid here of increasing seasonality, it is consistent with the environment surrounding the two sites. As discussed below, there was a large river system between Tepe Marani/Gurga Chiya and Bakr Awa, which would have contained areas of marshes. It is possible that the flax was cultivated in these marshy areas, with irrigation during the dry summer months from the river itself.

Returning now to the phytolith evidence: a water availability index was calculated for the onsite samples (Table 2). The values are consistently above 50\% throughout the period (Late Neolithic to Chalcolithic periods), suggesting relatively high soil water availability, with some fluctuations, especially during the Late Neolithic, indicating fluctuations in water availability. The average percentage is somewhat higher during the later Chalcolithic of Gurga Chiya (at 71\%), that is about 6500-5500 BP (4550 - 3550 BCE), compared to that of the Late Neolithic/Chalcolithic transition (63\%; around $7500-7000$ BP $(5550-5050 \mathrm{BCE})$ ) at Tepe Marani, which tentatively (given sample size) could indicate that there was more water availability (and thus increased precipitation) during the later period. A recent paper by Clark et al. (2016) shows climatic variability in the $4^{\text {th }}$ millennium BCE and greater aridity from around $3600-3700$ and $3100-3300$ BCE in parts of the Near East. While we cannot be sure that this is the case in our results, we do note that samples GC13F-304 and GC13E-1522, which date to around $3600 \mathrm{BCE}$, might suggest wetter conditions. These onsite phytolith samples, however, likely reflect economic use; therefore, they do not directly clarify the issue of climate change.

The sedimentary and phytolith data indicate a fairly stable, temperate climate, with some evidence of increasing seasonality, with increasing winter rainfall and possibly drought conditions at times during the summer months. The offsite sedimentary and phytolith records indicate that the surrounding environment was one of an anabranching river system, with a riparian environment on the banks and floodplain. There is a presence of both grasses and trees/shrubs, and the environmental conditions were relatively water abundant, at least until the Achamaenid period (i.e., at around $2450 \mathrm{BP} / 500 \mathrm{BCE}$ ). By that period, there is evidence of a hydrology shift, which could be the result of climate change (increased aridity, although conditions are still temperate, as evidenced by the presence of pooid grasses; Marsh and Altaweel, In Press). The phytolith results from Trench D were very similar to those of Trench 1, indicating a riparian environment. The upper layers, however, contained pottery and dark organic matter, indicating likely colluvium from the 
site or possibly purposeful dumping by Gurga Chiya inhabitants, and soil formation processes. This may have been a tributary of the main river channel.

The water availability index for Trench 1 has values that range mainly above $90 \%$, indicating that for the most part, the samples come from channel deposits. There are exceptions, including P024, where the values dip down to about 50\%. It may be that this part of the channel became somewhat drier for a short period of time, due to slight channel movement. The results from Trench D are more varied. The bottom of the trench has lower values, around $63 \%$, indicating possibly overbank deposits. The values go up to $95 \%$, and these deposits are likely channel deposits, showing the movement of the channel over time. Then the values dip back down to 54\% in Sample GC13D-1004, which could be indicative of the colluvial nature of the sedimentary deposit.

Taken altogether, the evidence indicates a temperate climate with ample rainfall during Gurga Chiya/Tepe Marani occupation periods in the mid-Holocene. Archaeological results, including terraced architecture, suggest that episodic flooding and high water levels could have been a major concern for the inhabitants of Gurga Chiya. On the other hand, the macrobotanical remains suggest possible mitigation strategies for drought. The phytolith and sedimentary records indicate there was a riverine system that supported the continued growth of wetland plants and a galleried forest in the vicinity. However, the climate did vary, with increasing winter rains and seasonality, which likely led to some drought summers and limited irrigation. This trend continued, with some variation, throughout most of the Holocene until some point after the Achaemenid period (i.e., around $2450 \mathrm{BP} / 500 \mathrm{BCE}$ or later), when drier conditions appear to have become more prevalent, based on sedimentary results.

\section{Paleoclimate and Other Proxy Comparisons}

Although stalagmites SHC-01 and SHC-02 cover fairly short intervals, they allow us to draw some preliminary conclusions, particularly when compared to other paleoclimate records from the Middle East (Figure 8). The $\delta^{18} \mathrm{O}$ of the middle Holocene stalagmite SHC-02 are 1\%o more negative compared to the late Holocene stalagmite SHC-01, identical to stalagmites from Soreq and Jeita Caves. More negative $\delta^{18} \mathrm{O}$ values during the early and middle Holocene are also evident in $\delta^{18} \mathrm{O}$ records from Turkey (Eski Acigöl, Roberts et al., 2011), Iran (Zeribar and Mirabad; Stevens et al., 2001; 2006), Lebanon (Jeita Cave; Cheng et al., 2015) and Israel (Soreq Cave and Negev desert; Bar-Matthews et al., 2003; Goodfriend, 1999) and indicative of enhanced rainfall between $\sim 10,000$ and 6000 years ago. The late Holocene stalagmite (SHC-01) suggests relatively drier conditions, which corresponds to the sedimentary record from Trench 1, although climatic variability is evident, with potentially more pronounced drought. Dust records from northern Iran (Neor Lake; Sharifi et al., 2015) and the northern Red Sea (GeoB 5804-4, Arz et al., 2003) provide supporting evidence for increased rainfall and reduced mobilization of dust during the early and middle Holocene (Figure 8). Unfortunately, stalagmite SHC-02 does not cover the termination of the humid period (Arz et al., 2003) in most parts of the Middle East between 6300 and 5000 years ago. However, pollenbased reconstructions of summer (JJA) and winter (NDJ) rainfall in Lebanon (e.g., 
Chamsine; Cheddadi et al., 2016; Figure 8) suggest fairly constant rainfall and enhanced seasonality until approximately 2000 years ago.

While there is fairly consistent evidence for substantial increase in precipitation during the early to mid-Holocene in the Middle East, it remains uncertain whether seasonality (winter-spring precipitation versus summer drought) was higher or lower during this period. The presence of annual layers in stalagmite SHC-02 suggest a highly seasonal climate with one rainy season, which is supported by the occurrence of annual growth bands in several stalagmites from the Middle East (e.g., Fleitmann et al., 2004; Fleitmann et al., 2003; Cheng et al., 2009; Flohr et al., 2017). There is, thus, clear evidence in northern Iraq for a highly-seasonal climate between at least 8025 (6075 BCE) \pm 38 and 6977 (5027 BCE) \pm 219 years BP. Possibilities for the early Holocene include minimal seasonality (e.g., Dean et al., 2017) or dry springs and summers and wet winters (Lewis et al., 2017; Wick et al., 2003). It has been suggested that the weakening of the Indian Summer Monsoon may have coincided with increasing rains evident by the mid-Holocene ( 6300 cal. BP) in neighboring Anatolia and NW Iran (Djamali et al., 2010). On the other hand, climate model experiments (Brayshaw et al., 2011) suggest that summer precipitation did not increase substantially in northern Arabia and from Syria to Iran during the early and mid-Holocene as the Intertropical Convergence Zone and the associated monsoonal rainfall belt were located south of these areas. This is also in good agreement with the interpretation that longer and possibly more severe summer droughts may have delayed the distribution of deciduous oak in the Middle East, which occurred approximately 3000 years later than the onset of the humid period.

Figure 8 here

\section{Conclusion}

Integrating the various proxy results, spanning archaeological, sedimentary, phytolith, and speleothem data, the benefits of using multiple proxies are indicated. These records suggest relatively wet and temperate conditions spanning parts of the mid-Holocene. Late Holocene sedimentary, phytolith, and speleothem records indicate that the onset of drier conditions likely occurred over the last 2500 - 2000 years, although it was still wet enough for rainfed agriculture. We recognize that further work is needed to better understand our existing trends and to more fully understand environmental change in other periods. More phytolith samples are needed from better-preserved contexts, while analyses of further speleothems are needed to complete the Holocene sequence. Nevertheless, results presented here are unique to this part of the Near East, as multiproxy data are rarely used in regions such as Iraq. These results demonstrate how multiple proxies complement each other and help support conclusions for the region of analysis. We now have a better understanding of climate conditions in the northeastern part of Iraq, a key area in the development of agriculture and urban areas with a high-precision dating source. Shalaii Cave appears to have an abundance of other samples that span other periods within the Holocene, which we think makes it a potentially important cave in demonstrating the region's climatic history. 


\section{Acknowledgments}

We like to thank the British Institute for the Study of Iraq for funding parts of this research. We also thank Professor Larry Edwards from the University of Minnesota and his laboratory for dating our speleothem samples.

\section{References}

Al-Basrawi NH and Al-Jiburi HK (2014) Hydrogeology of the High Folded Zone. Iraqi Bulletin of Geology and Mining 6: 163-183

Al-Hafeed SBI (2016) Reconstructing of Paleoclimate through Hydrogeological and Environmental Studies of Shalaii Cave, SE of Sangaw, Iraqi Kurdistan Region. Msc thesis. College of Science at the University of Sulaimani. University of Sulaimani.

Alexandre A, Meunier J-D, Colin F and Koud J-M (1997) Plant impact on the biogeochemical cycle of silicon and related weathering processes. Geochimica et Cosmochimica Acta 61: 677-682.

Ali S (2007) Geology and Hydrogeology of Shahrizor - Piramagroon Basin in Sulaimani Area, Northeastern Iraq Ph.D. thesis. Faculty of Mining and Geology. University of Belgrade, Serbia.

Al-Jiburi HK and Al-Basrawi NH (2012) Hydrogeology of the low folded zone. Iraqi Bulletin of Geology and Mining 5: 133-157.

Altaweel M, Marsh A, Mühl S et al. (2012) New investigations in the environment, history, and archaeology of the Iraqi Hilly Flanks: Shahrizor Survey Project 20092011. Iraq 74: 1-35.

Altaweel M and Marsh A (2016) Landscape and geoarchaeology of the Bora Plain. In: Exploring the Neo-Assyrian Frontier with Western Iran: The 2015 Season at Gird-i Bazar and Qalat-I Dinka, K Radner, F Janoscha Kreppner, and Andrea Squitieri (Eds.). Pp. 23-28. Gladbeck: PeWe Verlag.

Arz H.W, Lamy F, Pätzold J et al. (2003) Mediterranean moisture source for an earlyHolocene humid period in the northern Red Sea. Science 300: 118-121.

Baba Sheikh S (2000) Hydrochemistry of cave and spring waters in (SangawChamchamal), Sulaimani Governance. MSc Thesis. Baghdad University, Baghdad, Iraq.

Badertscher S, Fleitmann D, Cheng H et al. (2011) Pleistocene water intrusions from the Mediterranean and Caspian seas into the Black Sea. Nature Geoscience 4: 236-239. 
Bar-Matthews M, Ayalon A, Gilmour M et al. (2003) Sea-land oxygen isotopic relationships from planktonic foraminifera and speleothems in the Eastern Mediterranean region and their implication for paleorainfall during interglacial intervals. Geochimica Et Cosmochimica Acta 67: 3181-3199.

Brayshaw DJ, Rambeau CMC and Smith SJ (2011) Changes in Mediterranean climate during the Holocene: Insights from global and regional climate modelling. The Holocene 21: 15-31.

Cabanes D, Weiner S and Shahack-Gross R (2011) Stability of phytoliths in the archaeological record: a dissolution study of modern and fossil phytoliths. Journal of Archaeological Science 38: 2480-2490.

Cheddadi R (2016) Climate change since the last glacial period in Lebanon and the persistence of Mediterranean species. Quaternary Science Reviews 150: 146-157.

Cheng H, Sinha A, Verheyden S et al. (2015) The climate variability in northern Levant over the past 20,000 years. Geophysical Research Letters 42: 8641-8650.

Cheng H, Edwards RL, Shen CC et al. (2013) Improvements in Th-230 dating, Th-230 and U-234 half-life values, and U-Th isotopic measurements by multi-collector inductively coupled plasma mass spectrometry. Earth and Planetary Science Letters 371: 82-91.

Clarke J, Brooks N, Banning, EB et al. (2016) Climatic changes and social transformations in the Near East and North Africa during the 'long' 4th millennium BC: A comparative study of environmental and archaeological evidence. Quaternary Science Reviews 136: 96-121.

Dean JR, Jones MD, Leng MJ et al. (2015). Eastern Mediterranean hydroclimate over the late glacial and Holocene, reconstructed from the sediments of Nar lake, central Turkey, using stable isotopes and carbonate mineralogy. Quaternary Science Reviews 124: 162-174.

Dean JR, Jones MD, Leng MJ et al. (2017) Seasonality of Holocene hydroclimate in the Eastern Mediterranean reconstructed using the oxygen isotope composition of carbonates and diatoms from Lake Nar, central Turkey. The Holocene. [Online] 95968361772132.

Djamali M, Akhani H, Andrieu-Ponel V, Braconnot P., et al. (2010) Indian Summer Monsoon variations could have affected the early-Holocene woodland expansion in the Near East. The Holocene 20(5): 813-820.

FAO (2008) Irrigation in the Middle East region in figures: Iraq. Aquastat Survey 2008. $16 \mathrm{pp}$. 
Fleitmann D, Burns SJ, Neff U et al. (2004) Palaeoclimatic interpretation of highresolution oxygen isotope profiles derived from annually laminated speleothems from Southern Oman. Quaternary Science Reviews 23: 935-945.

Fleitmann D, Burns SJ, Mudelse M et al. (2003) Holocene forcing of the Indian monsoon recorded in a stalagmite from Southern Oman. Science 300: 1737-1739.

Flohr P, Fleitmann D, Zorita E et al. (2017) Late Holocene droughts in the Fertile Crescent recorded in a speleothem from northern Iraq. Geophysical Research Letters 44: doi: 10.1002/2016GL071786.

Göktürk OM, Fleitmann D, Badertscher S et al. (2011) Climate on the southern Black Sea coast during the Holocene: implications from the Sofular Cave record. Quaternary Science Reviews 30: 2433-2445.

Goodfriend GA (1999) Terrestrial stable isotope records of Late Quaternary paleoclimates in the eastern Mediterranean region. Quaternary Science Reviews 18: 501-513.

ImageJ (2017) https://imagej.nih.gov/ij/. Accessed 4/7/2017.

Jenkins E, Baker A and Elliott S (2011) Past plant use in Jordan as revealed by archaeological and ethnoarchaeological phytolith signatures. In: Mithen, S and Black, E (eds), Water, Life and Civilisation: Climate, Environment and Society in the Jordan Valley. Cambridge: Cambridge University Press

Jex CN, Baker A, Fairchild IJ et al. (2010) Calibration of speleothem delta O-18 with instrumental climate records from Turkey. Global and Planetary Change 71: 207217.

Karim KH, Al-Barzinjy ST and Ameen BM (2008) History and geological setting of intermontane basin in the Zagros fold-thrust belt, Kurdistan Region, NE-Iraq Kamal H. Karim. Iraqi Bulletin of Geology and Mining 4(1): 21-33.

Lachniet, MS (2009) Climatic and environmental controls on speleothem oxygen-isotope values. Quaternary Science Reviews 28: 412-432.

Landmann G, Reimer A, Lemcke G et al. (1996) Dating late glacial abrupt climate changes in the 14,570 yr. long continuous varve record of Lake Van, Turkey. Palaeogeography, Palaeoclimatology, Palaeoecology 122: 107-118

Laneri N, Schwartz M, Ur J et al. (2015) Ritual and identity in rural Mesopotamia: Hirbemerdon Tepe and the Upper Tigris River Valley in the Middle Bronze Age. American Journal of Archaeology 119: 533-564. 
Lewis JP, Leng MJ, Dean JR et al. (2017) Early Holocene palaeoseasonality inferred from the stable isotope composition of Unio shells from Çatalhöyük, Turkey.

Environmental Archaeology1: 79-95.

Madella M and Lancelotti C (2012) Taphonomy and phytoliths: A user manual. Quaternary International 275: 76-83

Madella M, Jones MK, Echlin P, Powers-Jones A and Moore M (2009) Plant water availability and analytical microscopy of phytoliths: Implications for ancient irrigation in arid zones. Quaternary International 193: 32-40.

Marsh A and Altaweel M (In Press) The search for hidden landscapes in the Shahrizor: Holocene land use and climate in Northeastern Iraqi Kurdistan. In: New Agendas in Remote Sensing and Landscape Archaeology, D Lawrence, M Altaweel, G Phillip (Eds). Oriental Institute. Chicago: University of Chicago.

Miglus PA, Bürger U, Fetner RA et al. (2013) Excavation at Bakr Awa 2010 and 2011. Iraq 75: 43-88.

Namdar D, Zukerman A, Maeir AM et al. (2011) The 9th century BCE destruction layer at Tell es-Safi/Gath, Israel: integrating macro- and microarchaeology. Journal of Archaeological Science 38: 3471-3482

Nesbitt, M (2006) Identification Guide for Near Eastern Grass Seeds. London: Institute of Archaeology/UCL Press.

O’Brien C, Ruiz KSZ, Brown A et al. (2005) A sediment-based multiproxy palaeoecological approach to the environmental archaeology of lake dwellings (crannogs), central Ireland. The Holocene 15: 707-719

Omer, TMA (2011) Country Pasture/Forage Resource Profiles: Iraq. FAO (United Nations Food and Agriculture Organization) working paper. 34 pp.

Orland IJ, Bar-Matthews M, Ayalon A et al. (2012) Seasonal resolution of Eastern Mediterranean climate change since $34 \mathrm{ka}$ from a Soreq Cave speleothem. Geochimica et Cosmochimica Acta 89: 240-255.

Ramsey MN, Maher LA, Macdonald DA et al. (2016) Risk, reliability and resilience: Phytolith evidence for alternative 'Neolithization' pathways at Kharaneh IV in the Azraq Basin, Jordan. PLoS ONE 11(10): e0164081

Roberts N, Reed JM, Leng MG et al. (2001). The tempo of Holocene climatic change in the eastern Mediterranean region: new high resolution crater-lake sediment data from central Turkey. The Holocene 11: 721-736. 
Roberts N, Brayshaw D, Kuzucuoglu C et al. 2011. The mid-Holocene climatic transition in the Mediterranean: Causes and consequences. The Holocene 21: 3-13.

Rohling EJ, Mayewski PA, Abu-Zied RH et al. (2002) Holocene atmosphere-ocean interactions: records from Greenland and the Aegean Sea. Climate Dynamics 18: 587-593.

Rohling EJ, Marino G and Grant KM (2015) Mediterranean climate and oceanography, and the periodic development of anoxic events (sapropels). Earth_Science Reviews 143: 62-97.

Rosen AM (2005) Phytolith indicators of plant and landuse at Çatalhöyük. In: Inhabiting Çatalhöyük: Reports from the 1995-99 Seasons, I Hodder (Ed.). Cambridge and London: McDonald Institute for Archaeological Research and British Institute of Archaeology at Ankara, pp. 203-212.

Rosen AM (2007) Civilizing Climate: Social Responses to Climate Change in the Ancient Near East. Plymouth: AltaMira Press.

Ryan P (2011) Plants as material culture in the Near Eastern Neolithic: Perspectives from the silica skeleton artifactual remains at Çatalhöyük. Journal of Anthropological Archaeology 30: 292-305

Sharifi A, Pourmand A, Canuel EA et al. (2015) Abrupt climate variability since the last deglaciation based on a high-resolution, multi-proxy peat record from NW Iran: The hand that rocked the Cradle of Civilization? Quaternary Science Reviews 123: 215230 .

Snyder, JA, Wasylik, K, Fritz, SC et al. (2001) Diatom-based conductivity reconstruction and palaeoclimatic interpretation of a 40-ka record from Lake Zeribar, Iran. The Holocene 11: 737-745.

Stevanovic Z and Markovic M (2004) Hydrogeology of Northern Iraq. Vol. 1. Climate, hydrology, geomorphology \& geology. Food and Agriculture Organization of the United Nations. Rome.

Stevens LR, Wright HE and Ito E (2001) Proposed changes in seasonality of climate during the Lateglacial and Holocene at Lake Zeribar, Iran. The Holocene 11: 747755 .

Stevens LR, Ito E, Schwalb A, Wright HE (2006) Timing of atmospheric precipitation in the Zagros Mountains inferred from a multi-proxy record from Lake Mirabad, Iran. Quaternary Research 66: 494-500. 
UN-ESCWA and BGR (United Nations Economic and Social Commission for Western Asia; Bundesanstalt für Geowissenschaften und Rohstoffe) (2013) Inventory of Shared Water Resources in Western Asia. Beirut.

van Zeist W (1966) Late Quaternary vegetation history of Western Iran. Review of Palaeobotany and Palynology 2: 301-311

van Zeist W and Woldring H (1978) A postglacial pollen diagram from Lake Van in East Anatolia. Review of Palaeobotany and Palynology 26: 249-276

Wengrow D, Carter R, Brereton G et al. (2016) Gurga Chiya and Tepe Marani: New excavations in the Shahrizor plain, Iraqi Kurdistan. Iraq 78: 253-284.

Wick L, Lemcke G and Sturm M (2003) Evidence of Lateglacial and Holocene climatic change and human impact in eastern Anatolia: high-resolution pollen, charcoal, isotopic and geochemical records from the laminated sediments of Lake Van, Turkey. The Holocene 13: 665-675.

Wright HE (1980) Climatic change and plant domestication in the Zagros Mountains. Iran 18: 145-148. 